\title{
SUOMESSA VILJELTYJEN OMENALAJIKKEIDEN SÄILYVYYDESTÄ VARASTOSSA
}

\author{
E. A. Jamalainen \\ Maatalouskoelaitoksen kasvitautiosasto, Tikkurila
}

Saapunut 10.6. 1953 .

Maassamme puuttuu tarkempia tietoja siitä, millaisia vaurioita erilaiset haitalliset tekijät aiheuttavat varastoimisen aikana meillä kasvatetuissa omenalajikkeissa. Sen sijaan on pomologisessa kirjallisuudessa (mm. Meurman ja Collan 5; Lehtonen, 4) runsaastikin tietoja siitä, kuinka kauan omenalajikkeet säilyvät käyttökelpoisina talven kuluessa, vaikkakin yksityiskohtaisia kokeisiin perustuvia tutkimustuloksia tässäkin suhteessa puuttuu. Muissa maissa suoritetut kokeet osoittavat, että eri hedelmälajikkeiden kestävyys varastossa esiintyviä tauteja vastaan on vaihteleva, eri lajikkeiden arkuudessa kylmän vaurioille on selviä eroja, lajikkeet suhtautuvat eri lailla varastoimispaikan hiilihappoisuuteen jne. Tämän ovat näyttäneet mm. Tanskassa äskettäin julkaistut monivuotiset omenien varastoimiskokeet $(1,2)$. Kun meillä viljellään suurimmaksi osaksi toisia lajikkeita kuin naapurimaissamme ja samojenkin lajikkeiden tuleentumisaste on erilainen, ei muista maista ole saatavissa sellaisia tutkimuksiin perustuvia tietoja omenalajikkeiden säilyvyydestä varastossa, jotka soveltuisivat oloihimme.

Maatalouskoelaitoksen kasvitautiosastolla oli varastoimiskaudella 1952_-1953 alustavasti kokeiltavana eräitä tärkeimpiä Suomessa viljeltyjä omenalajikkeita. Näiden kokeiden tulokset selostetaan seuraavassa.

\section{Kokeiden järjestelystä}

Kokeet järjestettiin kolmessa paikassa. Lindön kartanossa Tenholassa omenat säilytettiin ns. Koldär-systeemin mukaan jäähdytetyssä varastossa. Toisena koepaikkana oli Tuotevälitys Oy:n varastokellari Herttoniemessä, Helsingissä, ja kolmantena varastoimispaikkana Maatalouskoelaitoksen kasvitautiosaston kellari Tikkurilassa.

Lindön kartanossa oli syksyllä 1952 kunnostettu entinen tilava, kivestä rakennettu tallirakennus hedelmien säilytyspaikaksi, johon voidaan varastoida n. 200 
Taulukko 1. Säilytyspaikojen lämpötilat ja kosteudet.

Table. 1. Temperature and humidity of stores.

Mahdolliset mittavirheet: lämpötilassa

Margin of error: for temperature

$0.3^{\circ}$

kosteudessa $3 \%$

for humidity

\begin{tabular}{lcccccc}
\hline & $10 / 10$ & $15 / 10$ & $19 / 10-$ & $27 / 1-$ & $8 / 3-$ & Keskim. \\
Varasto - Storage house & $15 / 10$ & $19 / 11$ & $27 / 1$ & $8 / 3$ & $18 / 4$ & Average \\
\hline
\end{tabular}

Lämpötila - Temperature $^{\circ} \mathrm{C}$.

$\begin{array}{lllllll}\text { Herttoniemi } & 4.0 & 3.3 & 2.8 & 1.9 & 3.4 & 2.9 \\ \text { Lindö } & 4.3 & 3.7 & 3.8 & 3.7 & 4.6 & 4.0 \\ \text { Tikkurila } & 4.1 & 3.9 & 2.9 & 2.7 & 4.1 & 3.5\end{array}$

Suhteellinen kosteus — Relative humidity

$\begin{array}{lllllll}\text { Herttoniemi } & 85 & 81 & 78 & 68 & 75 & 77 \\ \text { Lindö } & 85 & 83 & 82 & 96^{1} & 95^{1} & 88 \\ \text { Tikkurila } & 93^{1} & 95 & 97 & 98 & 93 & 95\end{array}$

1 Varaston lattiaa kasteltu. - The floor of the storage house was moistened.

tonnia hedelmiä. Tänne oli sijoitettu ruotsalaisen Koldär-systeemin mukaan toimiva jäähdytyskoneisto. Koldär-järjestelmässä käytetään hyväksi ulkoilman lämpötilaa siten, että lietso imee tarvittaessa ulkoa kylmää ilmaa säilytyskellariin. Lietson toiminnan säätävät automaattisesti termostaatit. (Koldär-systeemistä omenien säilytyksessä, ks. lähemmin, 2). — Tuotevälitys Oy:n varastossa Herttoniemessä olivat omenat säilytyshuoneessa, jonka lämpötila jäähdytettiin ammoniakin käyttöön perustuvalla jäähdytyskoneistolla. - Tikkurilassa olivat omenat tavallisessa betonista rakennetussa kellarissa, jonka lämpötilaa säännösteltiin tuuletusluukuilla ja oviaukon kautta. - Säilytyspaikkojen lämpötilat ja kosteussuhteet selviävät taulukosta 1.

Koeaineisto oli kasvanut Lindön kartanossa ja kokeissa olivat seuraavat omenalajikkeet ja määrät:

The varieties of apples in experiments, number of apples and weight:

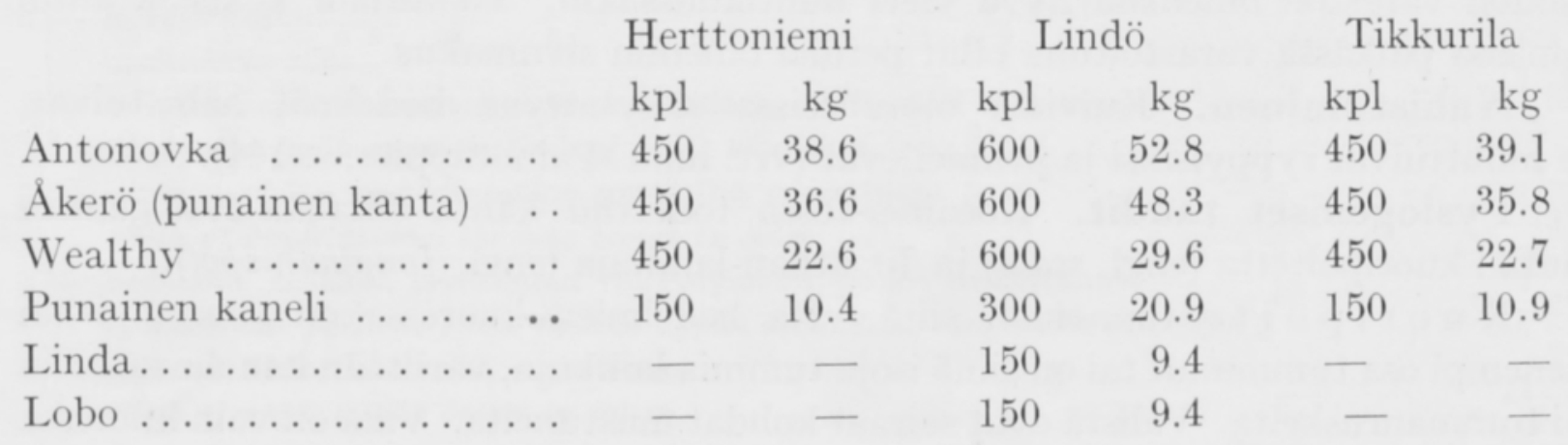


Koeaineisto säilytettiin hedelmälaatikoissa, joihin kuhunkin oli pantu omenia $150 \mathrm{kpl}$ (n. 8-12 kg) kolmeen kerrokseen ladottuna. Kunkin laatikon omenista oli $50 \mathrm{kpl}$ kääritty paperiin ja $100 \mathrm{kpl}$ paljaana. Lisäksi säilytettiin Lindön varastossa Antonovkaa, Åkerötä, Wealthyä ja Punaista kanelia yksi laatikollinen (150 kpl) pergamiinivillaan pakattuna. Tulokset eri tavoin säilytetyistä omenista on taulukoissa esitetty yhteisesti.

Koeaineisto varastoitiin lokakuun alussa ja omenien analysointi tapahtui 15. 11, 19. 12, 27. 1, 8. 3 ja 18. 4. Hedelmät punnittiin jokaisella kerralla, niissä olevat taudin ja muut vauriot määritettiin sekä osa hedelmistä (keskim. $10 \%$ ) halkaistiin tarkempia analyysejä varten.

\section{Omenissa todetut muntokset ja taudit varastoimisen aikana}

Ylikypsyminen. Hedelmien ylikypsyminen ilmeni kokeissa siten, että siementuppiloon rajoittuva malto alkoi ruskettua (kuva 1, asteet 1, 2, 3, 4). Ruskettuminen oli alussa hyvin lievää, tuskin huomattavaa (aste 1). Vähitellen malto siementuppilon alueella alkoi olla selvästi ruskettunutta (aste 2). Pitemmälle edistyessään ruskettuminen levisi myös laajemmalle siementuppilon ympärille (aste 3) ja lopuksi oli hedelmän malto kokonaan ruskettunut (aste 4). Taulukossa 2 on esitetty ylikypsymistä osoittavat analyysitulokset. Siinä on laskettu hedelmien keskimääräinen ruskettumisaste kuvan 1 asteikon mukaan. Kuten odottaa saattoi alkoi syysomena, Punainen kaneli, ylikypsyä jo syksyllä. Marraskuun puolivälissä oli suurin osa omenista ylikypsymisen vuoksi käyttökelvotonta. Muissa lajikkeissa oli todettavissa hieman ylikypsymistä joulukuun loppupuolella ja oli se jonkin verran lisääntynyt tammikuun loppuun mennessä, runsaimmin Wealthy- ja Lobo-lajikkeissa. Maaliskuun alussa oli ylikypsyminen näissä lajikkeissa kehittynyt pitemmälle niin, etteivät ne olleet enää käyttökelpoisia. Parhaiten säilyi Åkerö, jossa ylikypsyminen oli vielä varsin vähäistä huhtikuun loppupuolella. Antonovka oli tällöin jo pahemmin ylikypsynyttä. - Hedelmän mallon ruskettuminen siementuppilon ympärillä on kirjallisuudessa kuvattu usein erityiseksi fysiologiseksi taudiksi (eng. brownheart), jonka syistä ei aina olla lähemmin selvillä. Jatkuvat tutkimukset osoittanevat onko edellä selostettu omenan ruskettuminen yksinomaan ylikypsymistä.

Maku oli kaikissa ylikypsymiseltä ja taudeilta säilyneissä Herttoniemen ja Lindön varaston omenissa hyvä vielä huhtikuussakin. Tikkurilan kokeissa antoi samassa paikassa varastoituna ollut peruna omeniin sivumakua.

Nahistuminen. Kuivissa olosuhteissa säilytettynä hedelmät nahistuivat, ne muuttuivat ryppyisiksi ja pehmenevät (vrt. luku »Painotappio», s. 144).

Fysiogeniset taudit. Koeaineistossa todettiin kahta erilaista fysiogenista tautia: kuoripoltetta (engl. scald) ja Jonathan-laikkuja (engl. Jonathan spot).

K u o ripolte tunnetaan siitä, että hedelmien kuoressa on suurempi tai pienempi osa tummunut tai on siinä isoja tummia laikkuja, väriltään kanelinruskeita tai tummanruskeita. Välistä ovat sairaat kohdat mustuneita. Vika on vain kuoressa 
Taulukko 2. Ylikypsymisestä johtuva omenien ruskettuminen (vrt. kuva 1).

Table 2. Brownheart of apples during storage (cp. fig. 1).

Keskimääräinen ruskettumisaste

Koejäsentely — Variety

Average stage of discoloration

$15 / 11 \quad 19 / 12 \quad 27 / 1 \quad 8 / 3 \quad 18 / 4$

$\mathrm{H}$ e r t ton ie mi

$\begin{array}{llllll}\text { Antonovka } & 0 & 0.1 & 0.3 & 0.2 & 0.3 \\ \text { Åkerö } & 0 & 0.1 & 0.1 & 0.1 & 0.2 \\ \text { Wealthy } & 0 & 0.1 & 0.4 & 1.7 & 2.9 \\ \text { Punainen kaneli } & 0.5 & 1.7 & - & - & -\end{array}$

L i n d ö

Antonovka
Åkerö
Wealthy
Punainen kaneli
Linda
Lobo

0
0
0
0.6
0
0

0
0
0
1.8
0
0.4

0.2
0
0.4
2.3
0.2
0.6

0.7

0.9

(

$1.8 \quad 2.3$

Tik k u ril a

$\begin{array}{llllll}\text { Antonovka } & 0 & 0.2 & 0.2 & 0.4 & 1.8 \\ \text { Åkerö } & 0 & 0.1 & 0.1 & 0.1 & 0.1 \\ \text { Wealthy } & 0 & 0.2 & 1.2 & 2.3 & 3.8 \\ \text { Punainen kaneli } & 0.5 & 1.8 & 3.3 & - & -\end{array}$

Kuva 1. Omenien ruskettumisasteen luokittelu taulukossa 2. Fig. I. The classification of brownheart-stage in table 2.

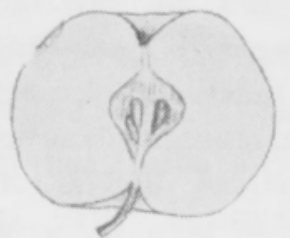

0

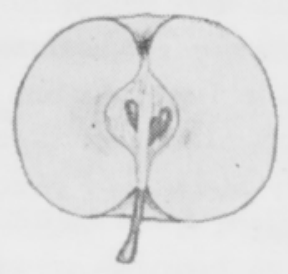

1

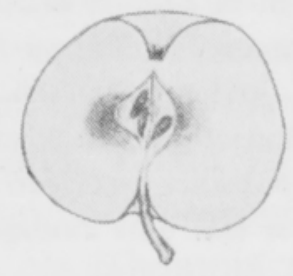

2

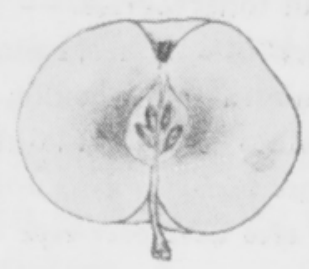

3

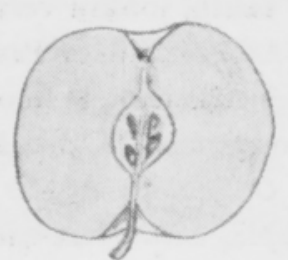

4

0 - ei ruskettunut non-áiscoloration

$\mathbf{1}=$ omenan malto siementuppilon ympärillä hyvin lievästi ruskettunut Slight discoloration in the flesh of apple around the core

$2=$ omenan malto siementuppilon ympäriltä ruskettunut Flesh of apple around the core brown in color

$3=$ hedelmän keskiosa laveammin ylikypsymisen vuoksi ruskettunut Considerable portions of the flesh of apples around the core brown in colour

$4=$ omenan malto kokonaan ruskettunut

Flesh of apple totally brown in colour 
Taulukko 3. Sienitaudit ja fysiogeniset taudit.

Table 3. Fungus aiseases and physiogenic diseases.

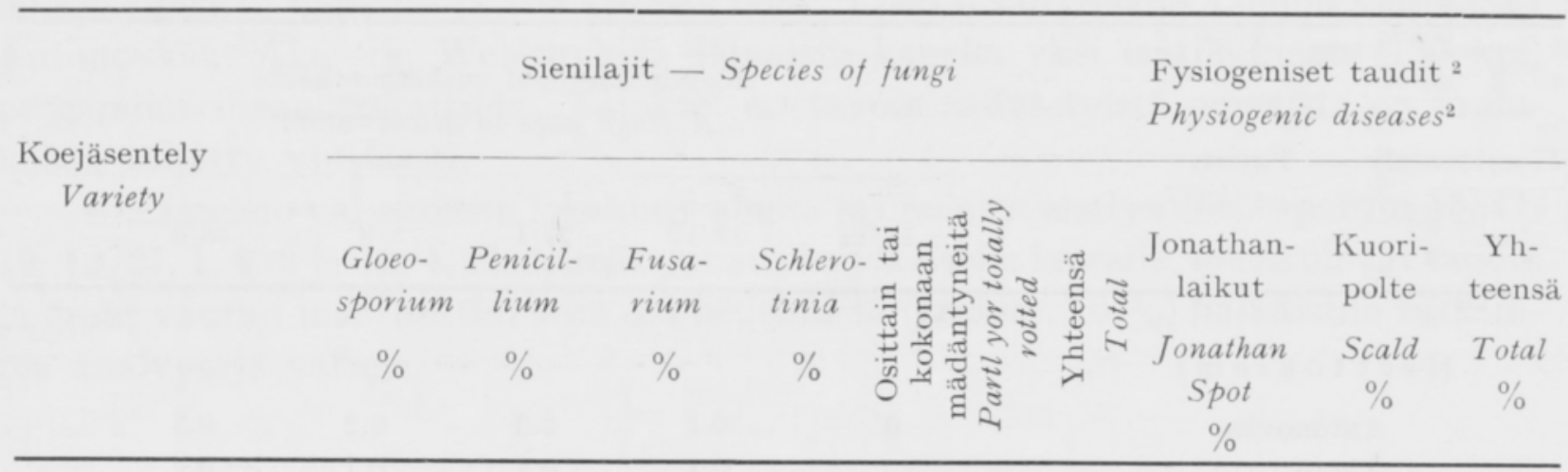

Herttonie mi

$\begin{array}{lrllllllll}\text { Antonovka } & 37.5 & 0 & 0 & 0 & 0.2 & 37.7 & 0 & 4.2 & 4.2 \\ \text { Åkerö } & 35.9 & 0.1 & 5.4 & 0 & 1.7 & 43.1 & 0 & 1.8 & 1.8 \\ \text { Wealthy } & 75.5 & 0 & 0 & 0 & 1.5 & 77.0 & 4.0 & 4.0 & 8.0 \\ \text { Punainen kaneli } & 1.5 & 0 & 0 & 0 & 0.7 & 2.2 & + & 0 & 0\end{array}$

L i n d ö

$\begin{array}{lcllllllll}\text { Antonovka } & 31.5 & 0.1 & 0 & 0.3 & 0.1 & 32.0 & 0 & 0.3 & 0.3 \\ \text { Ákerö } & 45.5 & 0.3 & 0.3 & 0 & 1.6 & 46.7 & 0.1 & 6.2 & 6.3 \\ \text { Wealthy } & 70.1 & 0 & 0 & 0 & 7.9 & 78.0 & 4.7 & 0 & 4.7 \\ \text { Punainen kaneli } & 15.2 & 0 & 0 & 0 & 16.5^{1} & 31.7 & + & 0.5 & 0.5 \\ \text { Linda } & 21.2 & 0.4 & 0 & 0 & 3.7 & 25.3 & 0 & 0 & 0 \\ \text { Lobo } & 9.2 & 0.4 & 0 & 0 & 2.0 & 11.6 & 0.2 & 0.4 & 0.6\end{array}$

T i k k u ril a

$\begin{array}{llllllllll}\text { Antonovka } & 55.5 & 0 & 0 & 0 & 0.9 & 56.4 & 0 & 0 & 0 \\ \text { Ákerö } & 77.3 & 0 & 2.6 & 0 & 2.8 & 32.7 & 0 & 9.6 & 9.6 \\ \text { Wealthy } & 80.1 & 0 & 0 & 0 & 12.1 & 92.2 & 8.4 & 0 & 8.4 \\ \text { Punainen kaneli } & 11.0 & 0 & 0 & 0 & 15.8^{1} & 26.8 & + & 0 & 0 \\ \end{array}$

$+=$ tautia jonkin verran todettavissa. - Some cases of disease were found.

1 Useimmissa Penicillium-hometta pinnassa - The surface of apples damaged by Penicillium.

2 Aineistossa huomioitu vain yksilöt, joiden ulkonäkö on fysiogenisten tautien vuoksi selvästi huonontunutta. Lähes kaikki Jonathan-laikkuiset omenat olivat ylikypsyneitä tai muuten pilaantuneita. Only those apples are included wose appearance was clearly damaged by physiogenic diseases. Almost all apples with Jonathan spot were over-ripe or otherwise damaged.

ja mallon pintasolukoissa. Hedelmät eivät näin ollen mädänny, mutta tauti alentaa hedelmien kauppa-arvoa. Kuoripoltetta alkaa esiintyä tavallisesti vasta pitemmän aikaa varastoituna olleissa hedelmissä. Kokeissamme esiintyi kuoripoltetta huomattavammin viimeisellä tarkastuskerralla, ja kuten taul. 3 nähdään oli sitä runsaimmin Åkerö-lajikkeessa Lindön ja Tikkurilan kokeissa. Kuoripolte lisääntyi nopeasti sen jälkeen kun hedelmät oli tuotu huonelämpöön.

Jonathan-laikut (nimitys johtuu amerikkalaisesta Jonathan-omenalajikkeesta) ovat pieniä, tummia, pistemäisiä laikkuja tai rengasmaisia taikka yhtenäisiä tummanruskeita tai ruskeita laikkuja hedelmien kuoressa. Laikut 

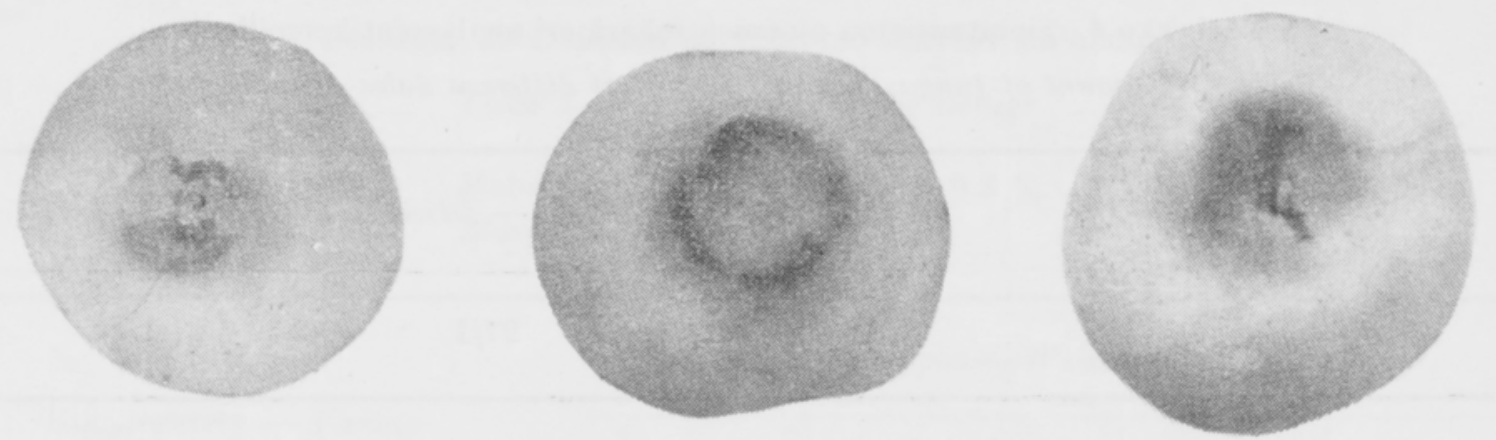

Kuva 2. Hedelmän varastolaikku (Gloeosporium album). Fig. 2. Rot of apples caused by Gloeosporium album.

eivät uletu maltoon. Jonathan-laikkujen, kuten kuoripoltteenkaan syistä ei olla perusteellisemmin selvillä. Tutkitussa aineistossa esiintyi Jonathan-laikkuja huomattavammin vasta viimeisellä tarkastuskerralla huhtikuussa (taul. 3) ja pääasiallisesti Wealthy-lajikkeessa. Taudilla ei ollut käytännöllistä merkitystä, sillä lähes kaikki hedelmät, joissa sitä runsaammin tavattiin, olivat jo joko ylikypsyneitä tai kokonaan ruskettuneita (mädäntyneitä).

Sienitaudit. Tärkein hedelmiä turmeleva sienitauti oli kokeissa Gloeosporium album OsTERW.-sienen aiheuttama, josta tässä kirjoituksessa käytetään nimeä h e d e $1 \mathrm{~m}$ än v a r a s t o l a i k k u (taul. 3). Sieni aiheuttaa varastoiduissa hedelmissä ruskeita, hieman sisäänpainuneita, jyrkästi terveeseen maltoon rajoittuvia, isokokoisia hedelmän maltoon ulottuvia laikkuja. Niitä ympäröi tavallisesti vyömäisesti leveä tummanruskea reunus, keskellä on musta kohta ja niiden väli on vaaleanruskea. Laikkujen keskiosaan ilmaantuu myöhemmin kuromapesäkkeitä, jotka ovat ensin pieninä harmaankellertävinä tai keltaisenruskeina nuppimaisina kohoutumina, muuttuen vähitellen valkoiseksi jauheeksi. Laikkuja on yksi tai useampia hedelmän pinnassa. Kun laikut laajenevat ja niitä ilmaantuu runsaammin, pilaantuu hedelmä lopuksi kokonaan. Laikut sijaitsevat joko hedelmän kyljessä, kannassa tai kärjessä (kuva 2). Analysoitaessa todettiin, että Wealthy- ja Linda-lajikkeissa laikut olivat enimmäkseen kannassa, Antonovkalajikkeessa taasen olivat laikut enimmäkseen kärjessä ja Åkerö-lajikkeessa pääasiallisesti sivuissa. Paitsi Gloeosporium album, voivat myös muut Gloeosporiumlajit turmella varastoituja hedelmiä, niistä yleisemmin G. fructigenum BERK. (vrt. 3, p. 172). Mikä osuus tällä ja muilla Gloeosporium-lajeilla on maassamme varastoitujen hedelmien turmelijoina ei ole lähempiä tietoja.

Penicillium-suvun sienet (v i h e r h o m e e n aiheuttajat) tekevät kirjallisuustietojen mukaan usein vahinkoa varastoiduissa omenissa; niistä on tärkein $P$. expansum Link (vrt. 3, p. 190). Taul. 3 on esitetty tapaukset, joissa omenien pilaantuminen oli todennäköisesti primäärisesti Penicillium-sienten aiheuttamaa. Sientä ei määritetty lajilleen; sen merkitys oli kokeissa vähäinen.

Fusarium-sienet aiheuttavat tässä kirjoituksessa t u p piloho m e e k i nimitetyn taudin. Siemenkotaa ympäröivä malto ruskettuu. Siemenkodan seinämien sisäpuolella voidaan todeta useasti valkeata tai vaaleanpunertavaa hometta. Lähemmin määritettäessä todettiin kysymyksessä olevan Fusarium avenaceum 
Taulukko 4. Sienitautisten omenien määrä eri analysointikerroilla.

Table 4. Amount of fungus-diseased apples at different dates of analyses.

Tautisia omenia - Diseased apples \%

Koejäsentely - Variety

$15 / 11 \quad 19 / 12 \quad 27 / 1 \quad 8 / 3 \quad 18 / 4$

Hert on i e mi

$\begin{array}{lllllr}\text { Antonovka } & 0 & 1.3 & 9.7 & 21.0 & 37.7 \\ \text { Åkerö } & 0 & 0.4 & 8.2 & 20.2 & 43.1 \\ \text { Wealthy } & 0.2 & 0.6 & 6.8 & 34.8 & 77.0 \\ \text { Punainen kaneli } & 0 & 2.2 & - & - & -\end{array}$

L in dö

$\begin{array}{lllrrr}\text { Antonovka } & 0 & 1.8 & 7.8 & 18.2 & 32.0 \\ \text { Ákerö } & 0 & 0.4 & 2.8 & 11.0 & 46.7 \\ \text { Wealthy } & 0 & 1.1 & 4.0 & 26.7 & 78.0 \\ \text { Punainen kaneli } & 0 & 2.2 & 12.4 & 31.7 & - \\ \text { Linda } & 0 & 0.4 & 9.3 & 14.0 & 25.3 \\ \text { Lobo } & 0 & 1.1 & 3.8 & 7.4 & 11.6\end{array}$

Tik kurila

$\begin{array}{lllrrr}\text { Antonovka } & 0 & 2.4 & 17.5 & 37.7 & 56.4 \\ \text { Åkerö } & 0.4 & 2.0 & 9.8 & 39.8 & 82.7 \\ \text { Wealthy } & 0.9 & 1.8 & 7.8 & 34.9 & 92.2 \\ \text { Punainen kaneli } & 0 & 4.4 & 26.8 & - & -\end{array}$

(FRIES) SACC.-lajin, joka myös kirjallisuuden mukaan (6) tunnetaan tuppilohomeen aiheuttajana. Koemateriaalissa esiintyi tuppilohometta Åkerö-omenassa, tosin ei kovin runsaasti. Taudin tiedetään pilaavan meillä usein Åkerö-omenaa jo kasvukauden aikana ja myös varastossa.

Sclerotinia fructigena Aderh. \& RUHL., k e l t a m u u m i o t a u d in aiheuttaja, joka turmelee hedelmiä kasvukauden aikana, voi pilata niitä myös varastossa. Tautia esiintyi kokeissa vain hieman Antonovka-lajikkeessa Lindössä.

Muista syistä kuin edellisistä sienitaudeista johtuen, oli osa analysoiduista hedelmistä joko kokonaan tai suurimmalta osaltaan ruskettuneita (mädäntyneitä, taul. 3), jolloin ei voinut varmuudella päätellä mikä oli syynä pilaantumiseen, ylikypsyminen vaiko bakteerien tai sienien aiheuttamat vauriot. Tällaisten ruskettuneiden omenien pinnassa oli usein Penicillium-sienten kuromajoukkioita.

Taul. 3 nähdään analyysitulokset eri taudeista ja taulukossa 4 sienitautien osuus. Tulokset osoittavat, kuten edellä jo mainittiin, että vahingollisin tauti kokeissa oli varastolaikku (Gloeosporium album), sillä pääosa pilaantuneista omenista oli tämän taudin turmelemaa. Muiden sienitautien merkitys oli verraten vähäinen, samoin fysiogenisten tautien. 
Taulukko 5. Omenien painotappio säilytyksen aikana.

Table 5. Weight losses during storage.

Mahdolliset punnitusvirheet $0.3 \%$

Margin of error $0.3 \%$

Painotappio - Weight loss \%

Koejäsentely - Variety

$15 / 11 \quad 19 / 12 \quad 27 / 1 \quad 8 / 3 \quad 18 / 4$

Herttonie mi

$\begin{array}{lrrrrr}\text { Antonovka } & 3.7 & 6.5 & 11.0 & 15.7 & 18.3 \\ \text { Ákerö } & 3.7 & 6.7 & 11.9 & 16.9 & 19.7 \\ \text { Wealthy } & 3.7 & 7.0 & 13.1 & 20.0 & 23.4 \\ \text { Punainen kaneli } & 4.8 & 10.7 & - & -\end{array}$

Lin d ö

$\begin{array}{lrrrrr}\text { Antonovka } & 3.6 & 6.4 & 9.4 & 12.6 & 15.1 \\ \text { Akerö } & 3.6 & 6.4 & 9.1 & 12.9 & 15.8 \\ \text { Wealthy } & 4.3 & 7.6 & 11.2 & 16.3 & 20.3 \\ \text { Punainen kaneli } & 4.6 & 9.0 & 13.8 & 26.2 & - \\ \text { Linda } & 3.2 & 5.8 & 8.7 & 13.3 & 16.6 \\ \text { Lobo } & 3.8 & 6.9 & 9.7 & 14.5 & 17.7\end{array}$

T i k k u i l a

$\begin{array}{lrrrrr}\text { Antonovka } & 3.5 & 4.8 & 6.3 & 7.3 & 9.5 \\ \text { Akerö } & 4.1 & 5.2 & 6.4 & 7.6 & 10.9 \\ \text { Wealthy } & 3.9 & 5.7 & 7.1 & 8.8 & 11.0 \\ \text { Punainen kaneli } & 4.4 & 8.6 & 10.6 & - & -\end{array}$

Tulokset taulukossa 4 osoittavat, että sienitauteja alkoi esiintyä joulukuussa, tällöin runsaimmin Punaisessa kanelissa. Tammikuussa oli taudin turmelemia useampia prosentteja ja maaliskuussa niiden merkitys oli jo varsin huomattava Tikkurilan kokeissa. Viimeisellä tarkastuskerralla oli tautisuus useimmissa tapauksissa ratkaiseva tekijä, sillä suuri osa, monissa tapauksissa yli puolet, oli sienien turmelemia. Pilaantuminen oli pahinta Tikkurilan kokeessa. Tässä tapauksessa täytyi kosteudella olla merkitystä, sillä varasto oli verraten kostea (taul. 1). Herttoniemessä ja Lindössä oli pilaantuminen vähäisempää ja kummassakin paikassa suunnilleen samaa suuruusluokkaa. Pahimmin pilaantui kokeissa Wealthy. Mainittakoon tässä yhteydessä, että tämä lajike joutui kesän 1952 loppupuolen kylmyyden ja kosteuden vuoksi korjuuseen tavallista pienikokoisempana ja valmistumattomana (ks. Wealthyomenan painot s. 2), joka on saattanut olla osaltaan syynä sen alttiuteen sienitaudeille. Toisella sijalla olivat Antonovka ja Åkerö; viimeksi mainittu pilaantui sangen voimakkaasti Tikkurilassa. Vähemmin oli pilaantuneita Lindassa ja Lobossa. Näistä Lobo ylikypsyy varhain, eikä ole enää kevättalvella käyttökelpoinen. 


\section{Painotappio}

Painotappio johtui kokeissa pääasiallisesti siitä, että omenat haihduttivat vettä säilytyksen aikana. Painotappiot olivat säilytyksen kuluessa (taul. 5) keskimäärin suurimmat Herttoniemen kokeessa, joka johtuu siitä, että ilma oli siellä verraten kuivaa (vrt. taul. 1). Kuivuminen on hedelmissä todettavissa visuaalisesti; ne alkavat nahistua jo tammikuussa ja lisääntyi nahistuminen kevääseen mennessä. Nahistuminen on todettavissa silloin, kun omenat ovat menettäneet yli $10 \%$ painostaan. Herttoniemessä olivat omenat jo tammikuun tarkastuksessa huomattavasti nahistuneita. Lindössä oli nahistuminen tammikuun tarkastuksessa vain lievää; maaliskuussa ja huhtikuussa se oli jo täälläkin hyvin tuntuvaa. Tikkurilassa ei todettu laisinkaan nahistumista.

\section{Paperoiminen ja pakkaus pergamiinivillaan}

Viimeisellä tarkastuskerralla oli Tikkurilassa paperoiduissa omenissa vähemmän tautisia kuin paperoimattomissa. Tässä kellarissa oli ilma kosteata, joten saastumismahdollisuudet olivat ilmasta käsin ilmeisesti paremmat kuin Lindössä ja Herttoniemessä, joissa ilma oli kuivempaa. Muissa tapauksissa ei paperoitujen eikä paljaiden hedelmien välillä ollut sanottavaa eroa.

Pergamiinivilla-pakkaus (Lindössä) ei vaikuttanut sienitautien esiintymiseen. Paperoiminen ja pergamiinivillaan pakkaus eivät vaikuttaneet myöskään fysiogenisiin tauteihin. Pergamiinivillaan pakattujen omenien painotappio oli aluksi hieman pienempi kuin sellaisenaan säilytettyjen (ero alle $1 \%$ ). Myöhemmin tämä vähäinen ero tasoittui.

\section{Yhteenveto}

Kokeissa olleet omenat säilytettiin varastoimiskaudella 1952-53 kohmessa paikassa: koneellisesti jäähdytetty varasto, varasto, jossa oli Koldär-systeemillä toimiva jäähdytys ja tavallinen betonikellari. Suhteellinen kosteus oli varastopaikoissa keskimäärin vastaavasti $68-85 \%, 82-96 \%$, ja $93-98 \%$; lämpötila vaihteli $4.3-1.9^{\circ} \mathrm{C}$ (taul. 1).

Koelajikkeista säilyivät parhaiten Åkerö, Antonovka ja Linda. Näissä lajikkeissa, joista viimeksi mainittu oli kokeiltavana vain yhdessä paikassa, olivat tautien vahingoilta säilyneet hedelmät käyttökelpoisia vielä viimeisessä, huhtikuun loppupuolella tapahtuneessa tarkastuksessa. Wealthy oli jo maaliskuun alussa ylikypsymisen vuoksi käyttökelvoton, samoin Lobo. Punainen kaneli oli jo marraskuussa ylikypsymisen vuoksi miltei käyttökelvoton.

Koeaineistossa todetuista taudeista oli pääasiallinen omenien turmelija hedelmän varastolaikku (Gloeosporium sp.). Tautia esiintyi jo maaliskuun ja varsinkin huhtikuun tarkastuksessa niin runsaasti, että se oli ratkaisevasti hedelmien 
säilymistä rajoittava tekijä (taul. 3 ja 4). Tautia esiintyi enimmin kosteassa varastopaikassa (ilman suht. kosteus 93-98\%) ja kaikissa säilytyspaikoissa Wealthylajikkeessa. Omenissa oli jonkin verran viherhometta (Penicillium sp.), hieman hedelmän muumiotautia (Sclerotinia fructigena STONEm. \& ADERH.) ja pieni osa omenista oli kokonaan tai suureksi osaksi ruskettunut (mädäntynyt), johon syytä ei tarkemmin määritetty. Åkerö-lajikkeessa oli tuppilohometta [Fusarium sp., määrityksen mukaan $F$. avenaceum (FRIES) SACC.] Fysiogenisista taudeista todettiin hedelmien kuoripoltetta (engl. scald) ja Jonathan-laikkuja (engl. Jonathan spot). Näiden merkitys oli verraten vähäinen; edellämainittua alkoi esiintyä varsinkin silloin kun hedelmät olivat olleet huonelämmössä ja viimeksimainittua pääasiallisesti vain ylikypsyneissä tai pilaantuneissa omenissa.

Omenien painotappio oli suurin, keskim. $20 \%$ kuivimmassa varastossa (ilman suht. kosteus $75-85 \%$ ), jossa hedelmät alkoivat nahistua jo tammikuusta lähtien. Kosteimmassa säilytyspaikassa (ilman suht. kosteus $93-98 \%$ ) oli painotappio n. $10 \%$ eivätkä hedelmät tällöin vielä laisinkaan nahistuneet.

Kirjoittaja esittää Maatalouskoelaitoksen kasvitautiosaston puolesta kiitokset vapaaherra, agronomi R. de la CHAPELLElle, joka luovutti omenat kokeita varten ja jonka maatilalla osa kokeista suoritettiin, Tuotevälitys Oy:lle, jonka varastokellarissa osa hedelmistä säilytettiin, sekä avusta kokeiden järjestämisessä maat. ja metsät. kand. J. Mukulalle. Edelleen esitetään kiitokset S u o m e n K u l tt u u rira has t o 11 e, joka oli myöntänyt v. 1949 kirjoittajalle apurahan kasvituotteiden varastoimistutkimuksia varten ja joihin tutkimuksiin tämä työ osaltaan liittyy.

\section{KIRJALLISUUTTA}

(1) Dullum, N. og Rasmussen, P. Molls. 1951. Forsøg med opvaring af aebler 1940-1948. Summary: Apple-Storage Experiments 1940-1948. Tidsskrift f. Planteavl., 54, p. 249-317.

(2) —— 1952. Frugtopbevaring. Samenligning af koldärlager og almindelig ventileret lager. Summary: Comparison between a common ventilated fruitstore and Koldär. Ibid., 55, p. 211 -236 .

(3) Gram, Ernst og Weber, Anna 1940. Plantesygdomme, p. 1-554. København.

(4) Lehtonen, Väinö 1946. Omenanviljely, p. 1-279. Porvoo-Helsinki.

(5) Meurman, Olavi ja Collan, Olavi 1943. Suomen hedelmäpuut ja viljellyt marjat. 1. osa, p. 1499. Helsinki.

(6) Wollenweber, H. W. und Reinking, O. A. 1935. Die Fusarien, p. 1-355. Berlin. 


\title{
S U M M A R Y :
}

ON STORAGE QUALITIES OF VARIETIES OF APPLES GROWN IN FINLAND

\author{
E. A. Jamalainen,
}

\author{
Agricultural Research Centre, Department of Plant Pathology, Tikkurila
}

During the storage period 1952 - 1953 preliminary experiments were made with some of the most important varieties of apples grown in Finland with regard to their storage qualities, at the Department of Plant Pathology. The apples for the experiments were received from the owner of Lindö estate, Baron R. DE LA ChApelle. The experiments were conducted at three different places, which are given in the tables of results under the names Herttoniemi, Lindö, and Tikkurila. At Lindö estate (Tenala) the apples were kept in a fruit cellar in Koldär store (cp. 2). In the store of Tuotevälitys Oy at Herttoniemi (Helsinki) the apples were kept in a refrigerated storage room. At Tikkurila the apples were kept in an ordinary ventilated store for potatoes. The temperature and humidity of the stores are given in Table 1. The varieties of apples used in the experiments (cp. p. 137) were kept in fruit boxes each containing 150 apples (about $8-12 \mathrm{~kg}$.). Test samples were put in storage at the beginning of October, and the analyses of the apples occurred on November 11, December 19, January 27, March 8, and April 18. Each time the apples were weighed, and diseases and other disorders determined.

\section{Results of the experiments}

Of the varieties tested, Åkerö, Antonovka, and Linda kept best. With these varieties, such apples as had not been infected with fungus diseases were still fit to be used at the time of the last examination, towards the end of April. Wealthy as well as Lobo was unmarketable already at the beginning of March, because of brownheart, (over-ripeness). The autumn variety Punainen kaneli was unmarketable already in November, due to over-ripeness (Table 2, Fig. 1).

The chief cause of damage by diseases was the rot of apples caused by Gloeosporium album Ostew. Already in March, and especially in April the disease was so common that it was cne of the factors decisively affecting the storage of apples (Tables 3 and 4, Fig. 2). The disease was commonest in the most humid store at Tikkurila (relative humidity of air e3-98\%) and in all stores in Wealthy. Blue mold (Penicillium sp.) and brown rot (Sclerotinia fructigena STONEM. \& ADERH.) occurred also to some extent, and a small number of the apples were altogether or to a great extent rotten, the cause of which was not determined. Åkerö variety was infected with internal browning caused by Fusarium fungi [F. avenaceum (FrIES) SACC.]. The significance of physiogenic diseases, scald, and Jonathan spots was comparatively slight; the former was found when the fruits had been kept at room temperature, and the latter was chiefly found in over-ripe or rotten apples only (Table 3 ).

The loss of weight (Table 5) was greatest, on the average $20 \%$, in the driest store (relative humidity of air 68-82\%) where apples began shrivelling already in January. In the most humid store (relative humidity of air $93-98 \%$ ) the loss of weight was about $10 \%$, and no shrivelling occurred. 